\title{
INFLUENCE OF COMPACTION OF A FOREST SOIL ON THE SOIL FAUNA IN A SUBTROPICAL REGION. I. ORIBATEI (ACARI, CRYPTOSTIGMATA) AND COLLEMBOLA (INSECTA)
}

\author{
Cláudio T. Ushiwata ${ }^{1}$ \\ Klaus Dieter Sautter 2 \\ Masato Kobiyama ${ }^{3}$
}

\begin{abstract}
An experiment to observe some changes of composition and population of Oribatei and Collembola was carried out on a Cambicsoil covered with Pinus taeda L. (Pinaceae). This study area is located on the Canguiri Experimental Station Center, Universidade Federal do Paraná, $20 \mathrm{~km}$ north to Curitiba city, Brazil. The climate of the area is subtropical. The observations resulted in a conclusion that the compaction strongly changes the structure of edaphic mesofauna community as the consequence of the modification of physical properties of soils.

KEY WORDS. Oribatei. Collembola, compaction, subtropical region
\end{abstract}

The Oribatei and Collembola contribute to the soil formation, feeding on coarse organic materials that are partially excreted in form of casts after undergoing enzyme action. The excrement is benefited by other organisms, giving humus as final product (PRIMAVESI 1979; THOMPSON \& EDWARDS 1974). The humus releases the mineral nutrients and indirectly influences soil fertility. TOMLIN (1975) affirmed that the Collembola are good indicators of soil fertility.

The porosity reduction of soil (soil compaction) decreases the air and water fluxe of soil (DICKERSON 1976; SANDS \& BOWEN 1979; WOLF \& HADAS 1984). This reduction is a factor limiting the edaphic mesofauna. In other words, the soil compaction determines members of the mesofauna and changes their population and composition (KING \& HuTCHINSON 1980). Hermosilla et al. (1977) demonstrated that the soil compaction affected the Collembola more than the Oribatei.

The objective of this study is to observe some changes of composition and population of the mesofauna due to compaction in a forest area.

1) Graduate Schools of Agriculture. Tokyo University of Agriculture and Technology. Fuchu-city, Tokyo 183, Japan.

2) Curso de Pós-graduação em Engenharia Florestal. Universidade Federal do Paraná. Caixa Postal 2959, 80001-970 Curitiba. Paraná. Brasil.

3) Departamento de Engenharia Sanitária e Ambiental, Universidade Federal de Santa Catarina. Caixa Postal 476, 88040-90() Florianópolis. Santa Catarina. Brasil. 


\section{MATERIAL AND METHODS}

The study area is located in the Canguiri Experimental Station Center, Universidade Federal do Paraná, 20km north to Curitiba city, Brazil. The area is covered with planted trees, Pinus taeda L. 29 years (Muniz et al. 1975) overlying a Cambicsoil. The climate in this area is classified as $\mathrm{Cfb}$, according to Koeppen classification (MAACK 1968). The annual precipitation and the mean temperature are $1.500 \mathrm{~mm}$ and $16,5^{\circ} \mathrm{C}$, respectively (MAACK 1968 ).

One line of trees was cutted systematically in March 1992. In the periphery of the line, there were intensive passes of a tractor. Than this zone suffered from a compaction influence strongly. In other zones, the selective felling was carried out. These zones did not have tractor passes and consequently received no compaction influence (Fig. 1). The soil physical properties of compacted and not compacted zones were analyzed by KoBIYAMA \& USHIWATA (1993).

Soil samples were collected for the chemical analysis in September 1993 (Tab. I). For the soil mesofaunal analysis, 11 soil samples, without litter, were collected randomly in each zone: $\mathrm{C} 1$ to $\mathrm{C} 11$ in the compacted zone and $\mathrm{N} 1$ to $\mathrm{N} 11$ in the not compacted zone; in September 1993. The samples were taken from surface soil layer $(0-5 \mathrm{~cm}$ depth) with the modified Berlese funnel method referred to SAUtTer \& Santos (1991). Each funnel had an area of $50 \mathrm{~cm}^{2}$. After field sampling, each funnel was immediately put into a plastic bag in order to prevent soil humidity loss. In a laboratory, all the funnels were left under lamps of $25 \mathrm{~W}$ for seven days. After that, the Collembola and the Oribatei were collected with a small flask containing liquid of $70 \%$ in alcohol, $28 \%$ in distilled water and $2 \%$ in glicerin. Identification and counting of mesofauna were carried out with a stereoscopic microscope. The classification of families of Collembola was subject to GISIN (1960) and that of groups of Oribatei was subject to BALOGH (1972).

This study treated all the populations and compositions of Oribatei and Collembola as those per funnel. The obtained data were transformed in $\sqrt{x+0,5}$ and then statiscally analyzed with a standard analysis of variance. The means were tested with Duncans multiple range test.

Table I. Chemical properties of soils in the studied area.

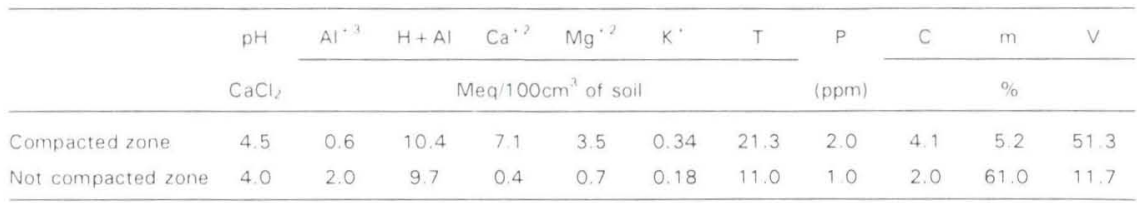

\section{RESULTS AND DISCUSSION}

Table II shows that difference of the total number of the Oribatei is significant between the two treatments (compacted and not compacted soils). This result is contrary to that of ARITAJAT et al. (1977) which obtained in agriculture land. 

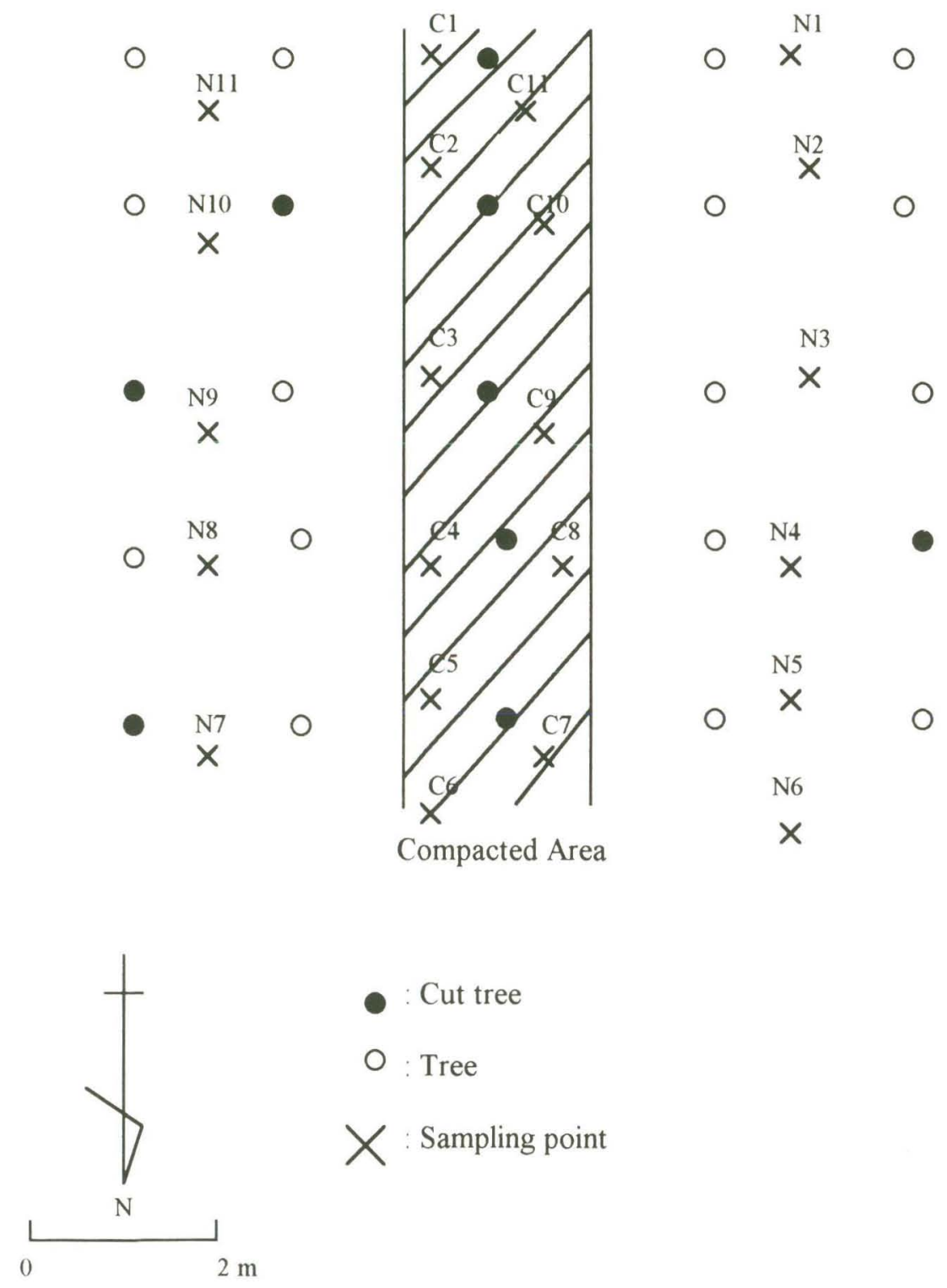

Fig. 1. The studied area and sampling points.

Among the groups of Oribatei, there is no statistical difference of the Apterogasterina and Pterogasterina between the treatments (Tab. II). Furthermore, difference of the Oribatei Inferior is significant between the treatments $(p=0.01)$, especially due to one species of the super-family Nothroidea. It indicates that because of its physiologically strong resistence. The Oribatei Inferior could survive under extremely unfavorate environmental conditions. 
Table II. Means of the populations of Oribatei, per funnel $\left(50 \mathrm{~cm}^{2}\right)$.

\begin{tabular}{llccc}
\hline & Oribatei & Apterogasterina & Pterogasterina & Oribatei Inferior \\
\hline Compactedzone & $29.91^{*}$ & 4.00 & 0.81 & $25.10^{*}$ \\
Not compacted zone & 13.36 & 6.18 & 1.00 & 6.18 \\
\hline
\end{tabular}

1) Significantly different by F-test: $\left({ }^{*}\right) \mathrm{p}<0.05,\left({ }^{*}\right) \mathrm{p}<0.01$.

The percentage of each group of Oribatei is shown in figure 2. The percentage of the Apterogasterina is decreased by compaction, though the difference in the population is not significant between the treatments. As mentioned above, the figure shows the dominat increase of the Oribatei Inferior due to compaction.

Table III shows the statistical difference of the families of Collembola between the treatments. Considering the total number of the Collembola, it must be noticed that the not compacted zone had their larger population than the compacted zone. This result also agrees with that of ARITAJAT et al. (1977), in the agriculture land. KAISER et al. (1991) also gained the similar result in which the soil compaction decreased the population of Collembola by $65 \%$ in an agriculture land. These results imply that the not compacted areas have the better condition for Collembola to survive.

Table III. Means of the populations of Collembola, per funnel $\left(50 \mathrm{~cm}^{2}\right)$.

\begin{tabular}{lcccccc}
\hline & Collembola & Poduridae & Onychiuridae & Isotomidae & Entomobryidae Sminthuridae \\
\hline Compacted zone & 13.54 & 0.18 & 1.18 & 5.91 & $5.18^{*}$ & 1.09 \\
Not compacted zone & $26.98^{*}$ & 0.27 & $5.27^{*}$ & $19.45^{*}$ & 1.63 & 0.36 \\
\hline
\end{tabular}

1) Significantly different by F-test: $\left({ }^{*}\right) p<0.05,\left({ }^{* *}\right) p<0.01$.

The percentages of Poduridae and Sminthuridae are very low in both the treatments and their difference are not significant between the treatments (Fig. 3). This might result from the fact that the populations of the two families are normally small under low $\mathrm{pH}$ condition (Tab. I).

The Onychiuridae is more numerous in the not compacted zone than in the compacted zone, which difference significant between the treatments $(p=0.05)$. The Isotomidae is also more numerous in the not compacted zone with significant difference $(p=0.01)$. According to CHRISTIANSEN (1964), these two families are the euedaphic type of mesofauna. It means that they inhabiting only the interior of soil. According to KOBIYAMA \& USHIWATA (1993), compaction influenced the soil physical properties till the depth of $20-30 \mathrm{~cm}$. The alteration of soil properties due to compaction might influence the population of such euedaphic mesofauna as these two families, worsening the physical soil properties.

On the contrary, in the case of Entomobryidae, its population is larger in the compacted zone with significant difference at $p=0.01$. CHRISTIANSEN (1964) explained that this family inhabits soil surface and litter horizon. In the case of the present study, it could be thought that this family inhabited a thick litter horizon 


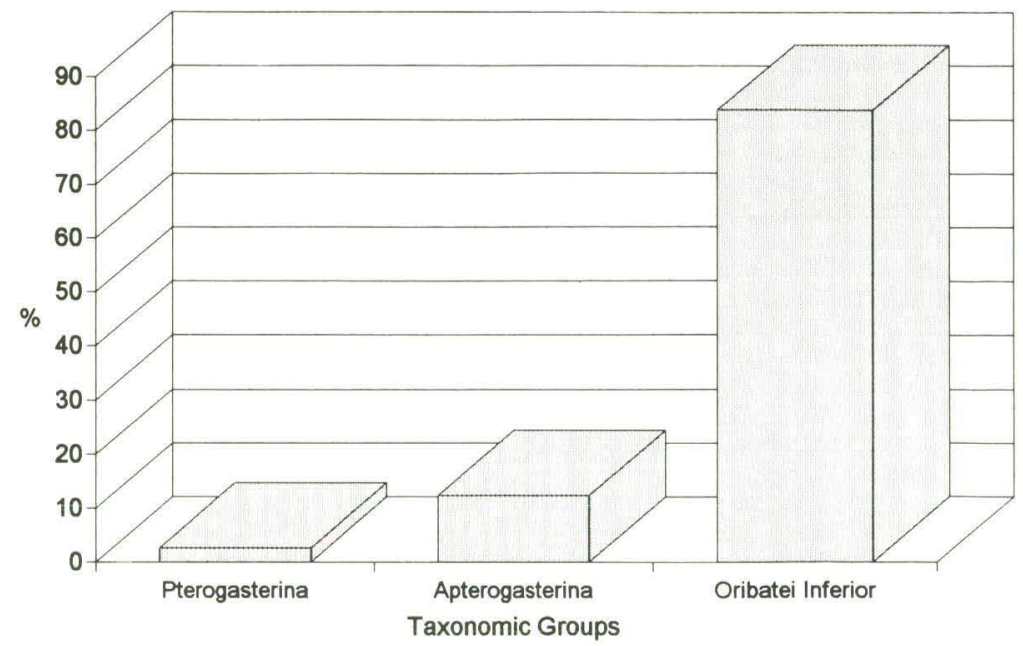

(a)

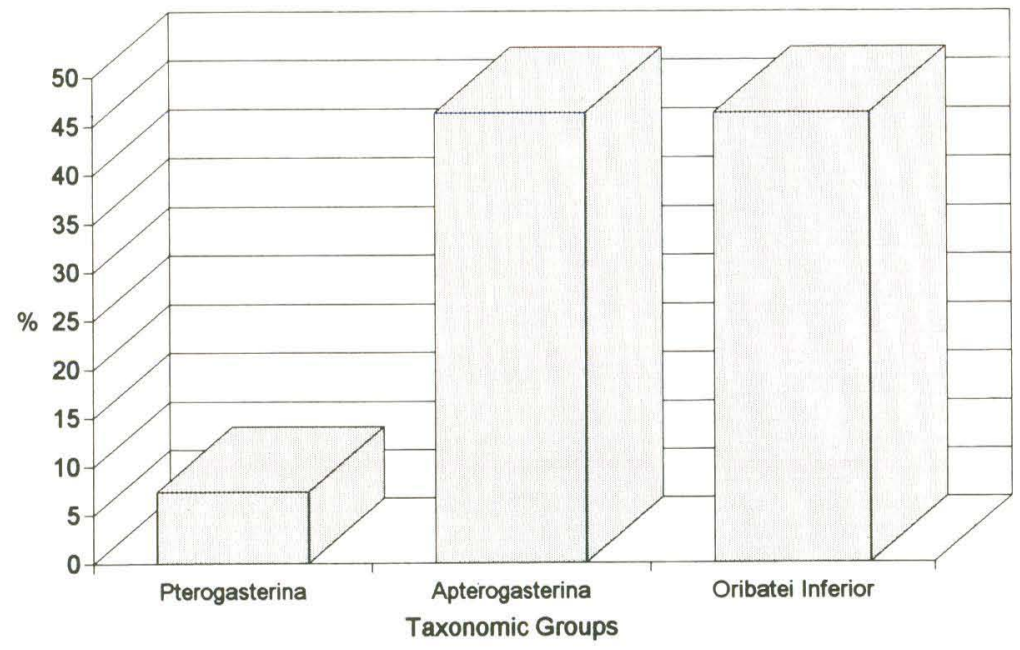

(b)

Fig. 2. Percentage of populations of Oribatei groups. (a) In the compacted zone; (b) in the not compacted zone.

(about eight centimeters thickness) in the not compacted zone. Since the sample was taken from only the soil layer without litter horizon, the population of this family was small in the soil sample. On the other hand, the compacted zone had a thin litter-horizon (about $2.5 \mathrm{~cm}$ ). The Entombryidae did not have the sufficient habitat in this thin litter-horizon, and probably migrated to the soil layer and survived where the soil sample was collected.

Figure 3 shows the calculated percentage of the families of Collembola in the present study. Though this result is similar to that obtained by ARITAJAT et al. 


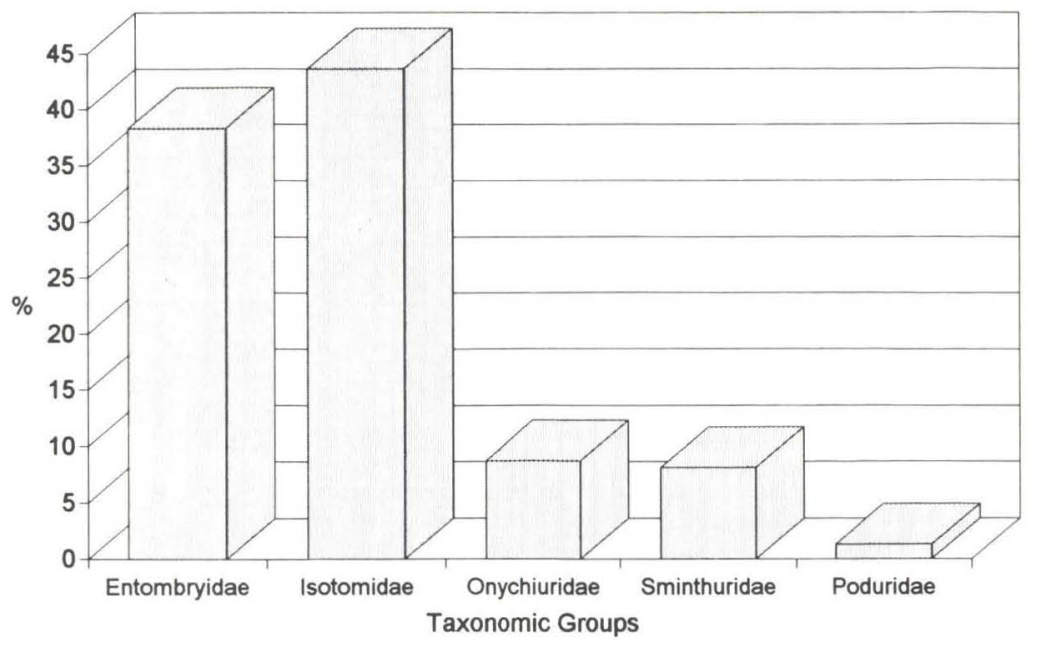

(a)

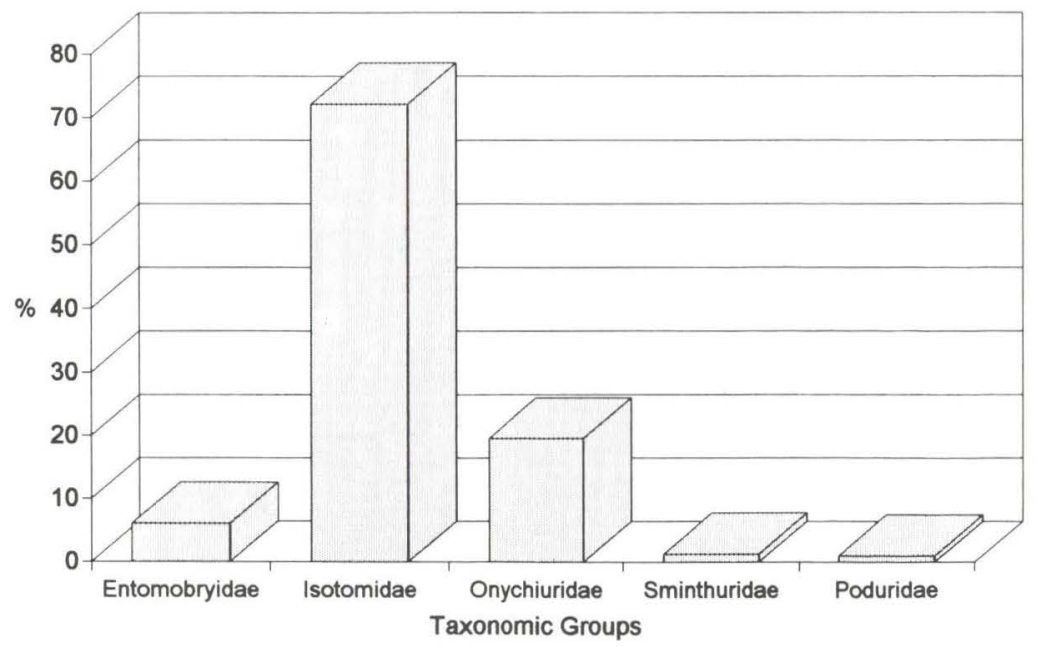

(b)

Fig. 3. Percentage of populations of Collembola families. (a) In the compacted zone; (b) in the not compacted zone.

(1977); the individuals of the Isotomidae are more numerous in the present study than in the their one.

Figure 4 demonstrates the inverse percentage of Oribatei and Collembola between the treatments. The compacted zone has major percentage of the Oribatei, principally owing to the increase of population of Oribatei Inferior. The not compacted zone has major percentage of the Collembola, which is resulted of the increase of population of the Isotomidae.

Revta bras. Zool. 12 (4): 905 - 913, 1995 


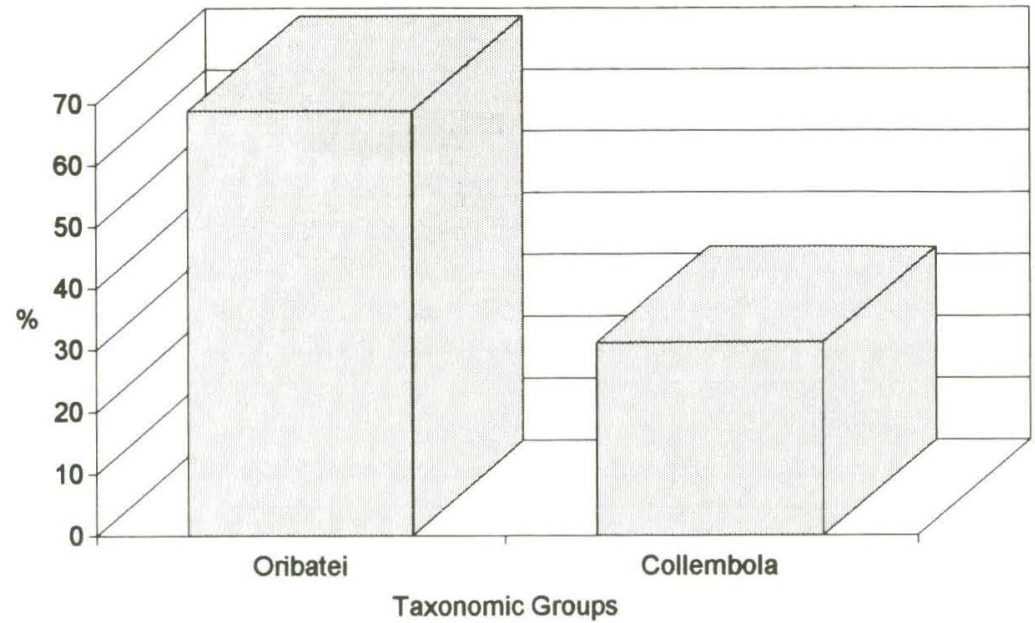

(a)

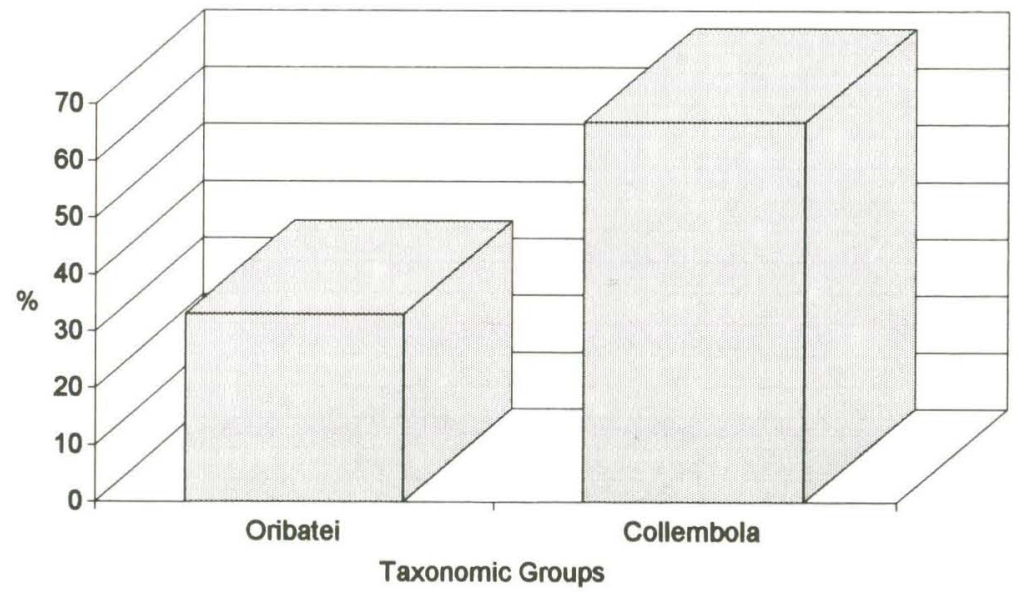

(b)

Fig. 4. Percentage of populations of Collembola and Oribatei. (a) In the compacted zone; (b) in the not compacted zone.

\section{CONCLUSIONS}

The soil compaction changed populations of both Oribatei and Collembola. Among the groups of Oribatei Apterogasterina and Pterogasterina did not suffer from the compaction influence. On the other hand, the population of Oribatei Inferior was increased by compaction.

Among the families of Collembola, the Poduridae and the Sminthuridae did not change their populations with compaction statistically. The populations of Isotomidae and Onychiuridae (euedaphic mesofauna) were larger in the not 
compacted zones, while that of Entomobryidae (epiedaphic mesofauna) was larger in the compacted one.

Based on the above mentioned results, it can be concluded that the compaction strongly changes the structure of edaphic mesofauna community as the consequence of the modification of physical properties of soils described by KOBIYAMA \& USHIWATA (1993). This conclusion agrees with that of KAISER et al. (1991) and is contrary to that of ARITAJAT et al. (1977) saying that the mechanical damage due to the compaction changes the community more than the modification of soil physical properties dues.

In this study, the mesofauna in litter horizon was not focussed. Since the population of the mesofauna inhabiting this horizon is significantly great, the research on the mesofauna in this horizon with relation to compaction would be necessary in future.

ACKNOWLEDGEMENTS. The autors are grateful to Dr. E. Franklin. Instituto Nacional de Pesquisas da Amazonia (INPA), for critical reading of this manuscript. Mr. L.M.P. Milla is thanked for a statistical analysis.

\section{REFERENCES}

Aritajat, U.; D.S. Madge \& P.T. Gooderham. 1977. The effects of compaction of agricultural soil on soil fauna. 1. Field investigations. Pedobiologia 17: 262-282.

Balogh, J. 1972. The Oribatid Genera of the World. Budapest, Akademiai Kiado, 181p.

Christiansen, K. 1964. Bionomics of Collembola. Ann. Rev. Entomol. 9: 147-178.

DiCKERSON, B.P. 1976. Soil compaction after tree-length skiddingin nothern Mississippi. Soil Sci. Soc. Am. J. 40: 965-966.

Gisin, H. 1960. Collembolenfauna Europas. Museum dHistoire Naturelle, Geneve, 312p.

Hermosilla, W.; A.R. Reca; J.A. Pujalte \& J. Rubio. 1977. Effectos de la compactation del suelo sobre la fauna edafica en campos pastoreados (Partido de Chascomus, Provincia de Buenos Aires - Argentina). Physis 36 (92): 227-236.

Kaiser, E.A.; C. Heisler; G. Walenzik \& O. Heinemeyer. 1991. The effect of mechanical soil compaction on microbial biomass development, Collembolan fauna, denitrification and mineralization in an agricultural location. Mitteilungen der Deutschen Bodenkundlichen Gesellschaft 66 (1): 531-534.

KinG, K.L. \& K.L. HuTCHINSON. 1980. Effects of superphosphate and stocking intensity on grassland microarthropods. J. Appl. Ecol. 17: 581-591.

KobiYAma, M. \& C.T. UshiWATA. 1993. Influence of compaction on physical properties of a forest soil. $1^{\text {st }}$ Panamerican Forestry Congress 1, Curitiba. 
p. 254-258.

MAACK, R. 1968. Geografia Física do Estado do Paraná. Curitiba, BNDEPR, $350 \mathrm{p}$.

Muniz, P.J.C.; Baldanzi, G. \& S.P. Netto. 1975. Ensaio de adubação em Pinus elliotti e Pinus taeda no sul do Brasil. Revista Floresta 5 (1): 5-13.

Primavesi, A. 1978. O Manejo Ecológico do Solo: Agricultura em Regiões Tropicais, São Paulo, 541 p.

SANDS, R. \& G.D. BowEN. 1979. Compaction of sandy soil in radiata pine forests. II. Effects of compaction on root configuration and growth of radiata pine seedlings. Aust. For. Res. 8: 163-170.

SAuTter, K.D. \& H.R. Dos SAnTos. 1991. Recuperação de solos degradados pela mineração de xisto, tendo como bioindicadores insetos da Ordem Collembola. Rev. Set. Ciênc. Agrár. 11 (1-2): 85-91.

ThOmpson, A. \& C.A. EDWARDS. 1974. Effects of pesticides on nontarget invertebrates in freshwater and soil, p.341-375. In: W.D. GuENZI (Ed.). Pesticides in soil and water. Soil Sci. Soc. of America.

Tomlin, A.D. 1975. Toxicity of soil application of insecticides to three species of springtails (Collembola) under laboratory conditions. Can. Ent. 107: 769-774.

Wolf, D. \& A. HADAS. 1984. Soil compaction effects on cotton emergence. Trans. Amer. Soc. Agric. Engineers 27: 655-659. 